\title{
Application of inflatable dam technology - problems and countermeasures
}

\author{
Paul W.M. Tam
}

\begin{abstract}
The history of the use of inflatable dams has been a long one in Hong Kong. The first three inflatable dams were constructed in the sixties as an integral part of the Plover Cove Water Supply Scheme. Up to December 1996, a total of 16 inflatable dams had been constructed. The use of rubber as a construction material has been subject to much skepticism. There are many reasons for this and one of them is clearly the problem of durability. Despite the many problems, rubber dams have been successfully implemented in Hong Kong. Most of the rubber dams in Hong Kong had been constructed by the Agriculture and Fisheries Department. Hong Kong Government, for the replacement of polluted agricultural weirs which were still in use. A rubber dam is inflatable and deflatable; when it is inflated, it serves as an agricultural weir (low-level dam) and when it is deflated it functions as a flood mitigation device. This note reviews the problems associated with the application of the technology in Hong Kong. Some countermeasures are suggested.
\end{abstract}

Key words: inflatable dams, flooding, flood mitigation, rubber, weathering, vandalism.

\begin{abstract}
Résumé : L'utilisation des barrages gonflables a connu une longue histoire à Hong Kong. Les trois premiers barrages gonflables furent construits dans les années soixante comme partie intégrante du schéma d'alimentation en eau de Plover Cove. Jusqu à décembre 1996, seize barrages gonflables au total furent construits. L'utilisation de caoutchouc comme matériau de construction fut sujet à beaucoup de scepticisme. Il y a plusieurs raisons à ceci, et l'une d'entre elles est clairement un problème de durabilité. Malgré leurs nombreux inconvénients. les barrages en caoutchouc furent implémentés avec succès à Hong Kong. La plupart des barrages en caoutchouc à Hong Kong furent construits par le département de l'agriculture et des pêches du gouvernement de Hong Kong, pour le remplacement des déversoirs agricoles pollués qui étaient encore utilisés. Un barrage en caoutchouc est gonflable et dégonflable: lorsqu'il est gonflé, il sert comme un déversoir agricole (barrage à faible hauteur) et lorsqu'il est dégonflé, il fonctionne comme un moyen d'atténuation de crue. Cet note révise les problèmes associés à l'application de cette technologie à Hong Kong. Quelques contremesures sont suggérées.
\end{abstract}

Mots clés : barrages gonflables, inondation, atténuation de crue, caoutchouc, dégradation, vandalisme. [Traduit par la rédaction]

\section{Introduction}

Rubber dams are installed to function as weirs or barrages which are relatively low-level dams constructed across a river for the raising of river level for the diversion of flow in full, or in part, into a supply canal or conduit for irrigation, domestic, or industrial use.

The first inflatable dam was developed by an American engineer, Norman Imbertson, Chief Operations Engineer in the mid-1950s for the Los Angeles Department of Water and Power. The product was known as Fabridam and was first marketed by Firestone Tire and Rubber Co. This early dam relies on water and air for inflation (Kahl and Ruell 1989). In 1968, Sumitomo Electric Industries Inc. acquired the inflatable dam technology from Firestone Tire and Rubber Co. and their first overseas installation was in Taiwan in 1977 for irrigation. Their second installation was on Tai Po Tau River, Hong Kong, in 1978. In 1978, Bridgestone Corporation introduced

Received April 14, 1997.

Revised manuscript accepted August 12, 1997.

P.W.M. Tam. Department of Civil and Structural Engineering, The University of Hong Kong, Pokfulam Road, Hong Kong.

Written discussion of this note is welcomed and will be received by the Editor until August 31, 1998 (address inside front cover). an air-inflated rubber dam in Japan and in the international market in 1982. The rubber dam at Indus River, Hong Kong, was one of their first overseas installations.

Although the use of inflatable dams is not very widespread in Hong Kong, many inflatable dams have been installed in Japan. It has been reported that approximately 2000 inflatable dams have been installed worldwide since the first installation (Moorthy et al. 1995). These dams are mainly used as the dam body for reservoirs for the provision of irrigation water for rice fields. These dams have a number of advantages, including the fact that they could be provided over a much longer span than those provided by steel gates. Also, rubber dams can be laid flat on river bottom without causing any obstruction to river flow.

\section{Dam material}

Two types of elastomers are used for the inflatable dams: neoprene and EPDM-armored (ethylene propylene diene monomer) rubber. The former is used by Sumitomo Electric Industries Inc. and the latter is used by Bridgestone Corporation. Some important characteristics of the elastomers are discussed below.

\section{Neoprene (chloroprene or polychloroprene)}

The material used in the earliest types of inflatable dams is 
Table 1. Rubber dams in Hong Kong.

\begin{tabular}{|c|c|c|c|c|c|c|c|}
\hline No. & Dam No. & River & Height $(\mathrm{m})$ & Width (m) & $\begin{array}{l}\text { Year of first } \\
\text { installation }\end{array}$ & Manufacturer $^{a}$ & Dam material \\
\hline \multicolumn{8}{|c|}{ Agriculture and Fisheries Department } \\
\hline 1 & BR8 & Beas & 1.6 & 13.04 & 1991 & $\mathrm{BC}$ & EPDM-R $\mathbf{R}^{b}$ \\
\hline 2 & BR9 & Beas & 1.4 & 13 & 1991 & $\mathrm{BC}$ & EPDM-R \\
\hline 3 & BR10 & Beas & 1.24 & 16.76 & 1991 & $\mathrm{BC}$ & EPDM-R \\
\hline 4 & BR11 & Beas & 0.70 & 10.8 & 1991 & $\mathrm{BC}$ & EPDM-R \\
\hline 5 & BR16 & Beas & 2.0 & 32.0 & 1992 & $\mathrm{BC}$ & EPDM-R \\
\hline 6 & YLN 65 & Kam Tin & 1.8 & 12.4 & 1992 & $\mathrm{BC}$ & EPDM-R \\
\hline 7 & YLN 117 & Kam Tin & 1.4 & 22.2 & 1992 & $\mathrm{BC}$ & EPDM-R \\
\hline 8 & YLN 162 & Yuen Long & 2.0 & 7.0 & 1992 & $\mathrm{BC}$ & EPDM-R \\
\hline 9 & YLN 189 & Yuen Long & 1.7 & 9.0 & 1992 & $\mathrm{BC}$ & EPDM-R \\
\hline 10 & YLN 191 & Yuen Long & 1.2 & 12.0 & 1992 & $\mathrm{BC}$ & EPDM-R \\
\hline 11 & YLN 160 & Yuen Long & 1.5 & 11.0 & 1994 & BC & EPDM-R \\
\hline
\end{tabular}

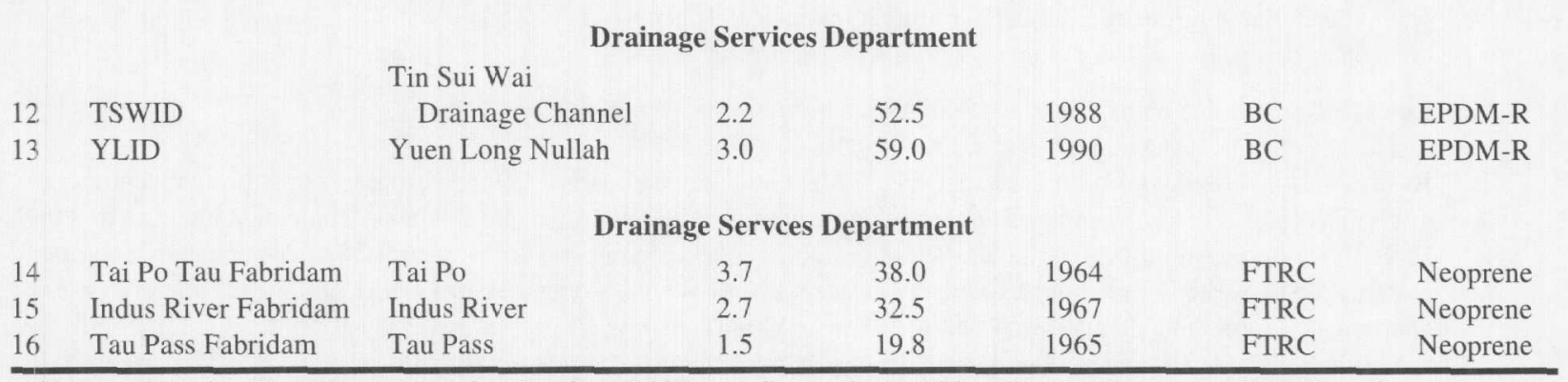

Notes: Rubber dam dimensions are based on data from Bridgestone Corporation and Water Supplies Department, Hong Kong Government. The width of a rubber dam corresponds to the width of the river.

${ }^{a} \mathrm{BC}$, Bridgestone Corporation; FTRC, Firestone Tire and Rubber Co.

${ }^{b}$ EPDM-R, ethylene propylene diene monomer armored rubber.

neoprene. Neoprene (polychloroprene) is the generic name for chloroprene polymers (2-chloro-1,3-butadiene) manufactured since 1931 by E.I. du Pont de Nemours \& Company (Forman 1973). Neoprene has superior weatherability, heat resistance, and low permeability to air and water vapor.

\section{EPDM-armored rubber}

EPDM (ethylene propylene diene monomer) has excellent resistance to weathering and good heat stability (Hamed 1992). They are fully saturated elastomers and they are the ultimate in ozone resistance (Ellul 1992).

\section{Inflatable dams in Hong Kong}

Both types of the inflatable dams are in operation in Hong Kong and are supplied by the manufacturers mentioned above. Both of these dams are patented. Although both dam types are strongly resistant to weathering, the rubber dams manufactured by Bridgestone Corporation have a thicker dam body and are considered by the Agriculture and Fisheries Department to be more resistant to abrasion and cut damage. A list of the inflatable dams in Hong Kong is given in Table 1.

Most rubber dams installed in Hong Kong are for irrigation and are usually small; the maximum width of an agricultural dam ever constructed was $32 \mathrm{~m}$ and the maximum height was $2 \mathrm{~m}$. The highest rubber dam installed in Hong Kong is $3.7 \mathrm{~m}$ high and it is used for water storage. Figure 1 shows the rubber dam locations in Hong Kong and Fig. 2 shows an agricultural rubber dam (BR16) in the inflated and the deflated modes.

\section{Problems associated with the rubber dams}

There are a number of problems associated with inflatable dams. The problems discussed below are a collection of the experience from the Water Supplies Department and the Agriculture and Fisheries Department for the inflatable dams.

\section{Vandalism}

A dam body is prone to damage by sharp objects. The vulnerability of the dams to vandalism suggests that it is an important consideration if a rubber dam should be constructed at a particular location at all. However, the experience gained from installation of rubber dams in Hong Kong indicates that the risk of vandalism is relatively small. Since the first agricultural rubber dam was in operation in 1992, the incidences of damage due to vandalism were relatively small. In one instance, a dam body was damaged. It was suspected that the dam was pierced by a sharp object by a person who was trying to deflate the dam for catching fish. In another instance, a control house was broken into through the louvre. It was found that the manhole cover inside the house was open but there was no damage to the instrumentation. There were no lightweight, valuable, detachable components in the control house.

Fencing of the dam site is an effective means for the avoidance of vandalism and is adopted by the Water Supplies Department. An alternative measure is the provision of a 24 -hour close circuit television monitoring system. The provision of this system itself deters vandalism. 


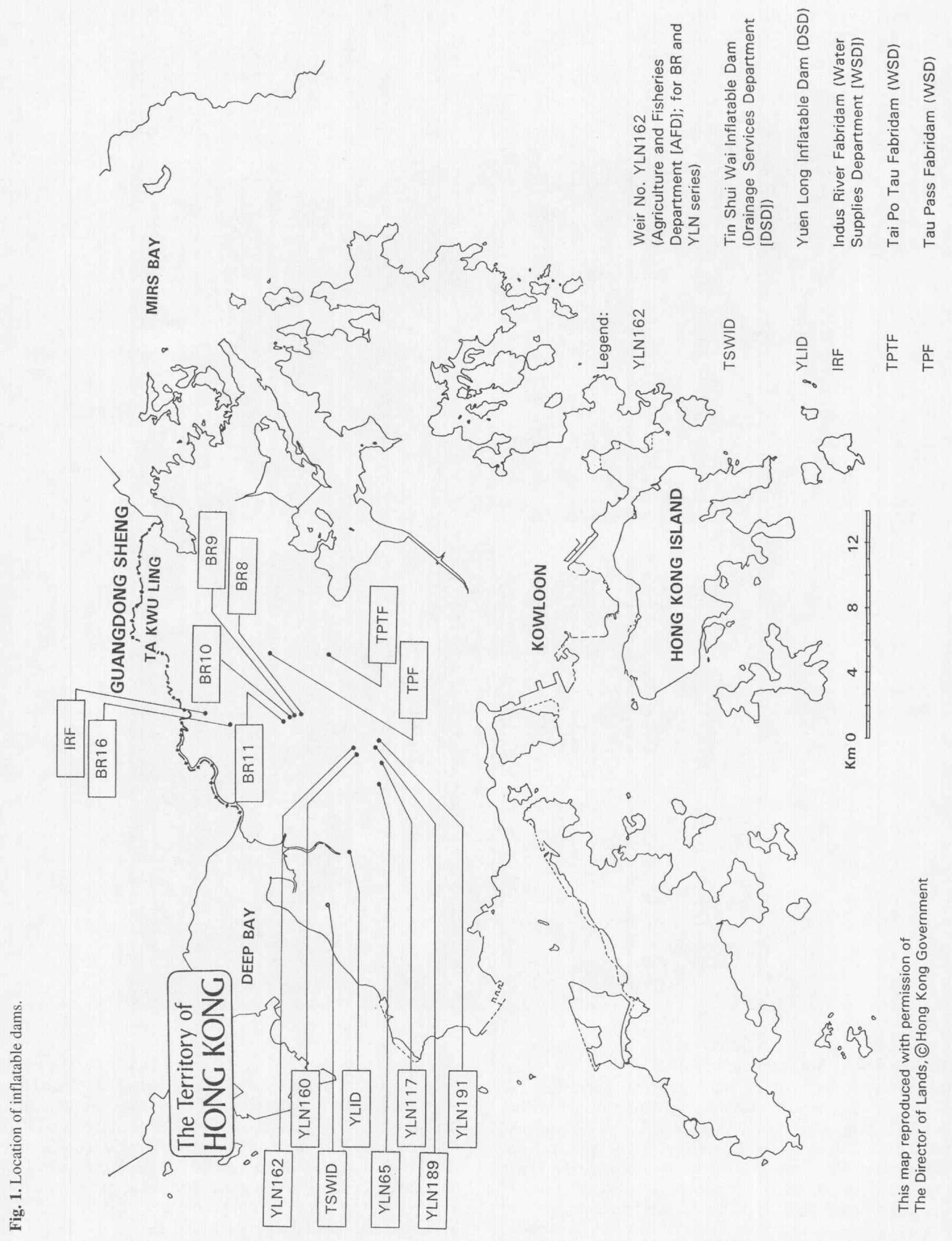


Fig. 2. Dam No. BR16 on Beas River.

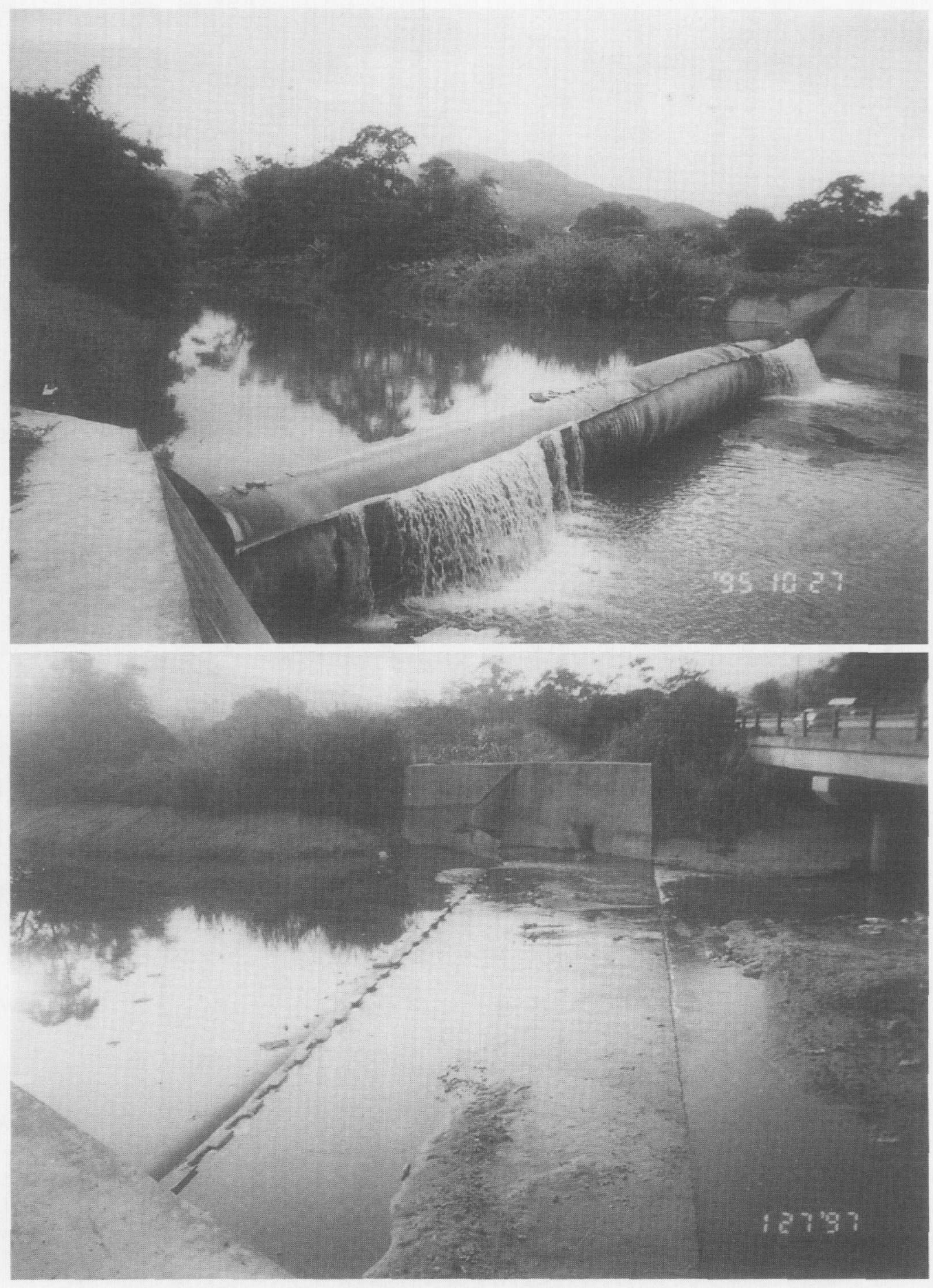

\section{Damage due to flow-induced vibration}

The rubbing of the inflatable body against the foundation and the sides of the dam can lead to wearing of the dam body. Local wearing will be accelerated if the inflatable dam body is rubbing against a sharp object or even a relatively smooth object such as a cobble. The Tai Po Tau dam (built by the Water Supplies Department) had experienced such damage recently. The darn body was partially deflated for the regulation of water flow and part of the dam body was in contact with the founda- tion. It was suspected that the abrasion effect due to "flow-induced vibration" was most severe at that point and a small hole was found at the bottom of the inflatable dam (Fig. 3). This mechanism of damage was supported by the discovery of a depression on the concrete foundation. The location of the depression mirrors the damage on the inflatable dam body. The smoothness of the surface suggests that it was found by a slow wearing process. Both the shape and size of the depression match the damage of the inflatable dam. 
Fig. 3. Tai Po Tau Dam on Tai Po River.
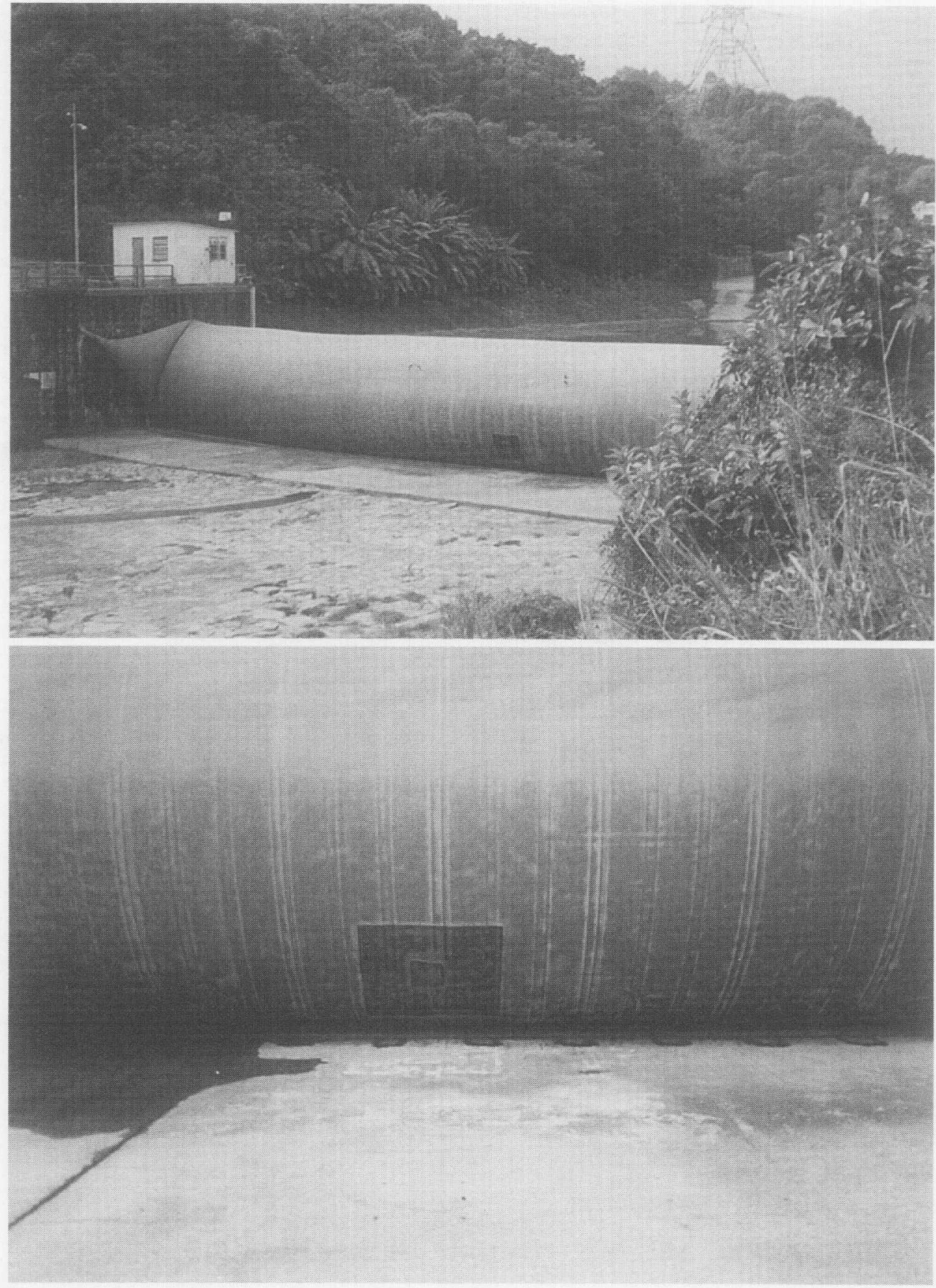

For the avoidance of flow-induced vibration, partial dam deflation should not be carried out unless it is absolutely necessary.

\section{Damage due to dam inflation and deflation}

During dam deflation, it is possible for the dam body be punctured by a sharp object immediately downstream of the dam. At Weir No. YLN 65, a puncture was discovered at the downstream side of the weir and a broken glass bottle was found to have caused the damage. Sharp objects deposited upstream of the the dam can also cause dam damage during dam inflation. Regular cleaning of the river beds both upstream and downstream of the dam is of help to avoid such damage.
Damage due to objects carried from upstream of the weir During severe rainstorms, rivers can become very violent and debris is often carried by the flood water. Water-borne sharp objects such as steel bars or metal frames could cause damage to the dam. Due to the extensiveness of flooding in Hong Kong, there has not been any effective measures provided to prevent such damage.

\section{Discussion}

\section{Repair of inflatable dams}

The repairs on the rubber dams are normally associated with 
punctures and cuts. The repair of punctures of inflatable dams is normally a very simple process. Dam repairs are infrequent. For example, only seven repairs were made during the period from March 1993 to June 1995.

\section{Contractual arrangement}

A special contractual arrangement is used by the Agriculture and Fisheries Department for the installation of the inflatable dams (386-392 1995). The important component of the specification is stated below:

The existing weirs are to be demolished with a new weir designed as a full width barrage to replace them. The lower part of the weir will comprise a concrete weir with a low crest or sill....

On top of the sill will be fitted a gate or barrage weir across the full width of the weir. The gate or barrage must be capable of opening, dropping or collapsing down flush with the sill level over the full width of the weir within one hour. No overhead mechanical equipment will be permitted over the full width of the weirs.

\section{Contractual claims}

Four contracts were awarded to four different contractors between April 1991 and December 1992. No contractual claims have arisen due to the contractual arrangement. It can be said that the contractual arrangement is reasonably well tested for further large-scale application. The average cost of a rubber dam is about HK\$150000 (CDN\$27 000) per metre width for the rubber dams installed by the Agriculture and Fisheries Department.

\section{Conclusions}

The use of rubber dams as agricultural weirs is a relatively new concept in Hong Kong. Due to the rubber material itself, there is often a concern if the dam material may be subject to re- peated damage due to vandalism. However, experience suggests that the installation of rubber dams is feasible in Hong Kong. It can be said that the use of a relatively innovative material in civil engineering is met with success in Hong Kong.

\section{Acknowledgements}

The author is grateful to the Director of Agriculture and Fisheries Department for his assistance and support rendered during the collection of information and data for this note. The views expressed in the note are those of the author's and do not represent the views of the Agriculture and Fisheries Department; and its director is not responsible for the accuracy of information contained in this note.

\section{References}

Ellul, M.D. 1992. Mechanical fatigue. In Engineering with rubber: how to design rubber components. Edited by A.N. Gent under the auspices of the Rubber Division of the American Chemical Society. Carl Hanser Verlag, Munich, Germany.

Forman, D.B. 1973. Rubber technology. 2nd ed. Edited by M. Morton. Sponsored by the Rubber Division of the American Chemical Society. Van Nostrand Reinhold Company, New York, N.Y.

Hamed, G.R. 1992. Materials and compounds. In Engineering with rubber: how to design rubber components. Edited by A.N. Gent under the auspices of the Rubber Division of the American Chemical Society. Carl Hanser Verlag, Munich, Germany.

Kahl, T., and Ruell, S. 1989. Flashboard alternatives including rubber dams. Proceedings, Waterpower '89, Niagara Falls, N.Y., pp. 447-456.

Moorthy, C.M.D., Reddy, J.N., and Plaut, R.H. 1995. Three-dimensional vibrations of inflatable dams. Thin-Walled Structures, 21: 291-306.

Tam, P.W.M. 1995. Procurement of specialised civil engineering facility by design and build contract. Proceedings, International Congress on Construction, Singapore, pp. 204-210. 